\title{
EVALUATION OF THE LEVEL OF GAMMA RADIATION DOSE ON SOME IMMUNE SYSTEM PARAMETERS AGAINST CANCER
}

\author{
AVALIAÇÃO DO NÍVEL DE DOSE DE RADIAÇÃO GAMA EM ALGUNS \\ PARÂMETROS DO SISTEMA IMUNOLÓGICO CONTRA O CÂNCER
}

\author{
Abdelmonsef Abdelaziz ELHADARY ${ }^{1}$; Ebtisam Abdelmageed MARZOOK ${ }^{\mathbf{1}}$; \\ Hanan Abdallah ABDELMONEM ${ }^{1}$ \\ 1. Biological Application Department, Nuclear Research Center, Egyptian Atomic Energy Authority, Cairo, Abou-Zabaal, Box 13759, \\ Egypt.abdelmonsef.elhadary@yahoo.com.
}

\begin{abstract}
The positive impact of exposure to low-dose gamma irradiation (LDR) on tumor regression and immune response has recently been emphasized. The present study aimed to investigate the Thelper 1/ T-helper 2 (Th1/ Th2) cytokine balance, serum protein changes in male BALB/c Ehrlich Ascites Carcinoma (EAC) bearing mice exposed to two low doses( $0.4 \mathrm{~Gy}$ or $0.8 \mathrm{~Gy})$ of gamma irradiation. Seventy two male BALB/C mice were divided into six groups. Group1: normal control; Group2\&3:mice were exposed to $\gamma$-irradiation at 0.4 and 0.8 Gray, respectively two times weekly for 3 weeks; Group4 (malignant control):mice were injected subcutaneously with $2 \times 10^{6}$ Ehrlich Ascites Carcinoma (EAC) cells/mouse; Group5\&6: mice were injected by EAC cells and exposed to $\gamma$-irradiation at 0.4 and 0.8 Gray, respectively two times weekly for 3 weeks, eight days after tumor transplantation. Data from the present study reported that two low-doses of $\gamma$ irradiation significantly increase the levels of serum IL2, IL6 and TNF $\alpha$ and a decrease the serum IL10 level in comparison to malignant control mice. The IL2 /IL-10,IL-6/IL-10 and TNF $\alpha /$ IL-10 (Th1/Th2 balance), were significantly increased in all tested groups when compared with control $(\mathrm{P}<0.05)$. Exposure to 0.8 Gy dose, however, induced significant elevation in all ratios in comparison to exposure to 0.4 Gy dose. This was associated with significant reduced tumor growth in mice implanted with Ehrlich Ascites Carcinoma, which was more pronounced in mice exposed to 0.8 Gy than mice exposed to 0.4 Gy dose. In conclusion, the present study suggests a possible immunomodulatory role of LDR as it was associated with Th1 cytokine polarization response, and $0.8 \mathrm{~Gy}$ have more positive effect than $0.4 \mathrm{~Gy}$. It also reinforces the beneficial effect of accumulated dose of total body irradiation $(0.4 \mathrm{~Gy}$ or $0.8 \mathrm{~Gy})$ in the regression of implanted Ehrlich Ascites Carcinomain BALB/c mice.
\end{abstract}

KEYWORDS: Ehrlich Ascites Carcinoma. $\gamma$-radiation. Cytokines.

\section{INTRODUCTION}

During the last years many investigations had showed that low-dose radiation (LDR) is more efficient in cancer therapy than the traditional daily doses of 1-2 Gy (SHIN et al., 2010), LDR has the ability to enhance the immune response (LIU et al. 2007). In addition to enhancing anti-tumor response LDR can also modify several other processes such as aging, adaptive response and survival (RATTAN, 2008).

Cytokines are group of soluble, lowmolecular-weight proteins that mediate immune and inflammatory responses. Currently cytokines are classified into, Th1 and Th2, as determined by their biological properties (AKDIS et al., 2011). The Th1 is characterized by the production of large amounts of IFN- $\gamma$,IL-2,TNF- $\alpha$, andTNF- $\beta$ to promote cellmediated immune response(KIDD, 2003). The Th2 cells produce IL-4, IL-10, IL-13, and IL-15 stimulating antibody production (KIDD 2003). Cytokines are also classified as pro-inflammatory e.g. IL-1, IL-6, IL-8, TNF- $\alpha$, IFN- $\gamma$ and antiinflammatory cytokines e.g. IL-4, IL-10, tumor growth factor beta (TGF- $\beta$ ), and vascular endothelial growth factor (VEGF) (WANG et al., 2009). The Th1/Th2 balance hypothesis arose in the late 1980 s, resulting from observations in mice of two subtypes of T-helper cells differing in cytokine secretion patterns and other functions. They suggested that the Th1/Th2 balance is important in modulating various immune and inflammatory responses (MOSMANN et al., 1986).

Thus the Th1/Th2 balance is important in modulating various immune and inflammatory responses (MOSMANN et al., 1986).

Enhancement of immune response with LDR treatment is one of the important factors responsible for improving therapeutic gain, (DUNN et al., 2004) this enhancement involves numbers of 
mediators including inflammatory cytokines produced by macrophages, epithelial cells, and fibroblasts (CHEN et al., 2005).The aim of this work was to evaluate the effect of two low doses $\gamma$ irradiation on some cytokine parameters, Th1/Th2 balance, total protein, albumin and globulin in normal and tumor bearing mice to reflect the functional status of the immune system.

\section{MATERIAL AND METHODS}

\section{Animals}

Seventy two male BALB/C mice weighing 16-21 g were used in the present study. Mice were housed in plastic cages located in the animal house of Nuclear research center, Inshas, under the same environmental conditions. They were acclimatized to the laboratory conditions prior to the study for seven days. The animals were kept at $25 \pm 2{ }^{\circ} \mathrm{C}$ and a relative humidity of $40-45 \%$ with alternative day and night cycles of $12 \mathrm{~h}$ each. They were fed on pelleted rat chow and water adlibitum. Anesthetic procedures and handling of animals were approved by and complied with the ethical guidelines of Medical Ethical Committee of the National Research Centre in Egypt (Approval number: 14077).

\section{Radiation}

Whole body $\gamma$-irradiation of mice was carried out at the National Centre for Radiation Research and Technology (NCRRT), Atomic Energy Authority, Egypt, using the Gamma Cell40 biological irradiator furnished with a Caesium 137 source. Animals were irradiated at a radiation dose level of 0.4 or $0.8 \mathrm{~Gy}$ for 3 weeks, two times/weak at dose rate $0.713 \mathrm{rad} / \mathrm{sec}$.

\section{Tumor transplantation}

Ehrlich Ascites Carcinoma (EAC) cells were chosen due to its high hematogenous metastatic propensity and reproducible biological behavior. EAC were supplied by the National Cancer Institute, Cairo University, Egypt. To asses a solid mass of Ehrlich tumor, a fixed number of $\left(2 \times 10^{6}\right)$ EAC cells suspended in $0.2 \mathrm{ml}$ PBS were inoculated subcutaneously into the right thigh region of male mice (Gothoskar; Ranadive, 1971) and left for 7-10 days to allow tumor to grow as big as its diameter achieved $0.7-1.2 \mathrm{~cm}$.

\section{Experiment}

The animals were randomly divided into six groups each group contain twelve mice

Group 1: normal control
Group2: mice were irradiated at a dose level of 0.4 Gray for 3 weeks, two times/weak (accumulation dose $=6 \times 0.4=2.4$ Gray).

Group3: mice were irradiated at a dose level of 0.8 Gray for 3 weeks, two times/ weak (accumulation dose $=6 \times 0.8=4.8$ Gray).

Group 4: malignant control mice (implanted by Ehrlich Ascites Carcinoma ,EAC)

Group5: eight days after tumor transplantation, malignant mice were irradiated at a dose level of 0.4 Gray for 3 weeks, two times/ weak (accumulation dose $=6 \times 0.4=2.4$ Gray) .

Group6: eight days after tumor transplantation, malignant mice were irradiated at a dose level of 0.8 Gray for 3 weeks, two times/ weak (accumulation dose $=6 \times 0.8=4.8$ Gray).

At the end of the experiment mice were fasted for $16 \mathrm{hrs}$, then slightly anaesthetized with ether afterward they were sacrificed by decapitation and the blood samples were collected and centrifuged at 3000 r.p.m. for 15 minutes to separate serum, that was kept in deep freezer at $-20{ }^{\circ} \mathrm{C}$ until used. Due to the limited blood volume of each mouse, serum samples of each two mice were pooled.

Interleukin IL-2 and IL-6 were measured using specific ELISA kits provided by DRG International Inc., USA. IL-10 was measured by Invitrogen ELISA kit. TNF- $\alpha$ was measured by Ray Bio mouse TNF- $\alpha$ ELISA kit using ELISA reader. Total protein and albumin were measured calorimetrically by spectrophotometer (Milton Roy Spectronic 1201) using commercial kits purchased from SPINREACT.

The sizes of tumor were measured by Caliper. The measurements were performed at the ends of first, second and third weeks for G4,G5 and G6 after eight days of tumor transplantation. Tumor volumes of solid Ehrlich Carcinoma were calculated using the formula

$\pi / 6(\mathrm{~L} \mathrm{x} \mathrm{W} \mathrm{x} \mathrm{H}) \mathrm{Cm}^{3}$ according to Mary et al. (1989).

Where, $\mathrm{L}=$ length of tumor, W= Width of tumor, $\mathrm{H}=$ Height of tumor

\section{Statistical Analysis}

The obtained data were presented as means \pm SD. One-way analysis of variance (ANOVA) was carried out using a statistical package program (COSTAT). A probability level of $\mathrm{P}<0.05$ was considered. 


\section{RESULTS}

Table 1 and figure1show mean values \pm SD and percent of the changes relative to normal control group for levels of IL2, IL6,TNF- $\alpha$ and IL10 in all tested groups were carried out. Comparing to the corresponding normal control group $(\mathrm{G} 1)$, the levels of IL-2, IL- 6 and TNF- $\alpha$ showed significant increases in all groups (G2-G6). In addition, comparing to malignant control groups (G4), mice inculcated with EAC cells followed by 0.4 or $0.8 \mathrm{~Gy}$ $\gamma$-irradiation (G5\&G6) showed significant increase of IL-2, IL-6 and TNF- $\alpha$ except IL-6 in G5 no significant change. There were significant decreases in IL10 in all the tested groups, compared to either normal or malignant control group.

Data represented as mean $\pm \mathrm{SD}$; Means with different superscripts in the same column are significantly different $(\mathrm{P}<0.05)$.

Table 1. Effect of $\gamma$-radiation exposure at 2.4 and 4.6 (accumulation of 0.4 and 0.8 respectively) on the levels of IL2, IL6, L10 and TNF- $\alpha$ in different animal groups.

\begin{tabular}{|c|c|c|c|c|}
\hline $\begin{array}{l}\text { Parameters } \\
\text { Groups }\end{array}$ & $\begin{array}{l}\text { IL2 } \\
(\mathrm{pg} / \mathrm{ml})\end{array}$ & $\begin{array}{l}\text { IL6 } \\
(\mathrm{pg} / \mathrm{ml})\end{array}$ & $\begin{array}{l}\text { IL10 } \\
(\mathrm{pg} / \mathrm{ml})\end{array}$ & $\begin{array}{l}\text { TNF- } \alpha \\
(\mathrm{pg} / \mathrm{ml})\end{array}$ \\
\hline Normal control (G1) & $64.23 \pm 2.23^{\mathrm{f}}$ & $19.89 \pm 1.034^{\mathrm{e}}$ & $127.58 \pm 5.08^{\mathrm{a}}$ & $40.71 \pm 2.43^{\mathrm{e}}$ \\
\hline Irradiated at $0.4 \mathrm{~Gy}(\mathrm{G} 2)$ & $198.04 \pm 3.31^{\mathrm{b}}$ & $99.67 \pm 2.52^{\mathrm{a}}$ & $53.86 \pm 2.93^{\mathrm{d}}$ & $103.93 \pm 3.46^{\mathrm{a}}$ \\
\hline Irradiated at $0.8 \mathrm{~Gy}(\mathrm{G} 3)$ & $234.43 \pm 4.22^{\mathrm{a}}$ & $86.09 \pm 2.47^{\mathrm{c}}$ & $43.09 \pm 2.49^{\mathrm{e}}$ & $81.31 \pm 3.63^{\mathrm{b}}$ \\
\hline Malignant control (G4) & $137.51 \pm 2.95^{\mathrm{e}}$ & $72.75 \pm 1.54^{\mathrm{d}}$ & $121.48 \pm 3.81^{\mathrm{b}}$ & $48.69 \pm 1.95^{\mathrm{d}}$ \\
\hline $\begin{array}{l}\text { Malignant + Irradiated at } 0.4 \\
\text { Gy (G5) }\end{array}$ & $153.51 \pm 2.59^{\mathrm{d}}$ & $70.84 \pm 2.21^{\mathrm{d}}$ & $102.37 \pm 3.10^{\mathrm{c}}$ & $56.17 \pm 2.38^{\mathrm{c}}$ \\
\hline $\begin{array}{l}\text { Malignant + Irradiated at } 0.8 \\
\text { Gy (G6) }\end{array}$ & $171.25 \pm 2.94^{\mathrm{c}}$ & $91.46 \pm 2.61^{\mathrm{b}}$ & $98.76 \pm 1.84^{\mathrm{c}}$ & $78.59 \pm 3.40^{\mathrm{b}}$ \\
\hline
\end{tabular}

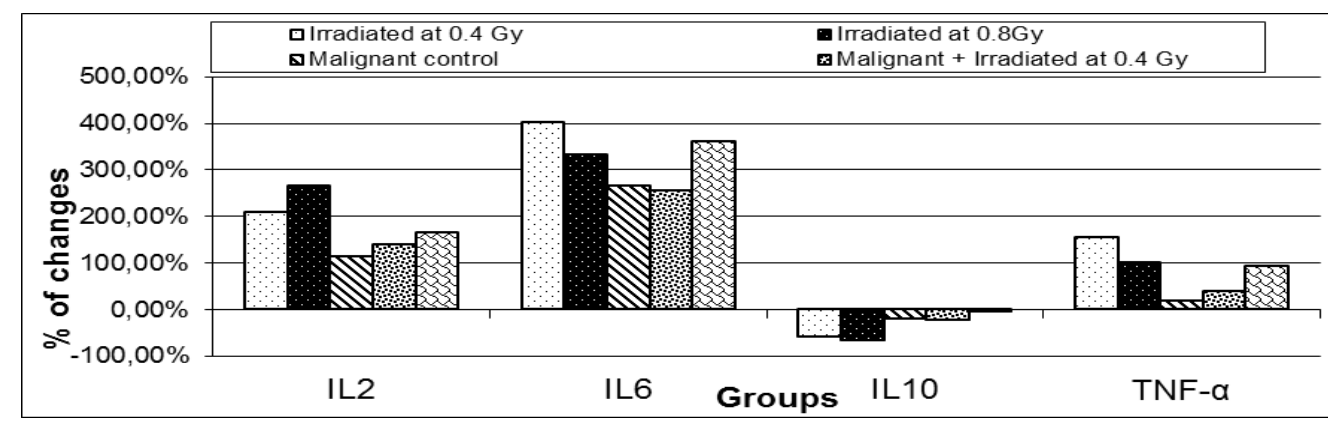

Figure 1. Illustrates the percent of the changes of IL2, IL6, L10 and TNF- $\alpha$ in all the tested groups in comparison to the corresponding normal control.

The ratios of IL2 /IL-10 (Th1/Th2 balance) were significantly increased in all the tested groups compared to the normal control $(\mathrm{P}<0.05)$. Moreover, IL2 / IL- 10 ratio increase significantly in malignant $+0.4 \mathrm{~Gy}$ irradiated mice groups (G5) and malignant +0.8 Gy irradiated mice group (G6) compared to malignant control (Figure 2). In addition, LDR at 0.8 Gy revealed significant elevation of IL2 / IL- 10 ratio compared to $0.4 \mathrm{~Gy}$ in comparing with normal or malignant control.

Figures 3 and 4 visualize the effect of the studies treatments on pro/anti-inflammatory cytokine ratio ( IL-6/IL-10 and TNF- $\alpha / \mathrm{IL}-10$ ) . All treatments significantly increased the IL-6/IL-10 and TNF- $\alpha /$ IL-10 ratios more than normal control $(\mathrm{P}<0.05)$. Figures 3 and 4 showed that the ratio of
IL-6/IL-10 and TNF- $\alpha$ /IL-10 were significantly increase in malignant $+0.4 \mathrm{~Gy}$ irradiated mice groups (G5) and malignant +0.8 Gy irradiated mice group (G6) compared to malignant control. Moreover, LDR at $0.8 \mathrm{~Gy}$ in G6 revealed significant elevation of IL-6/IL-10 and TNF- $\alpha$ /IL-10 ratios compared to 0.4 Gy in G5. 


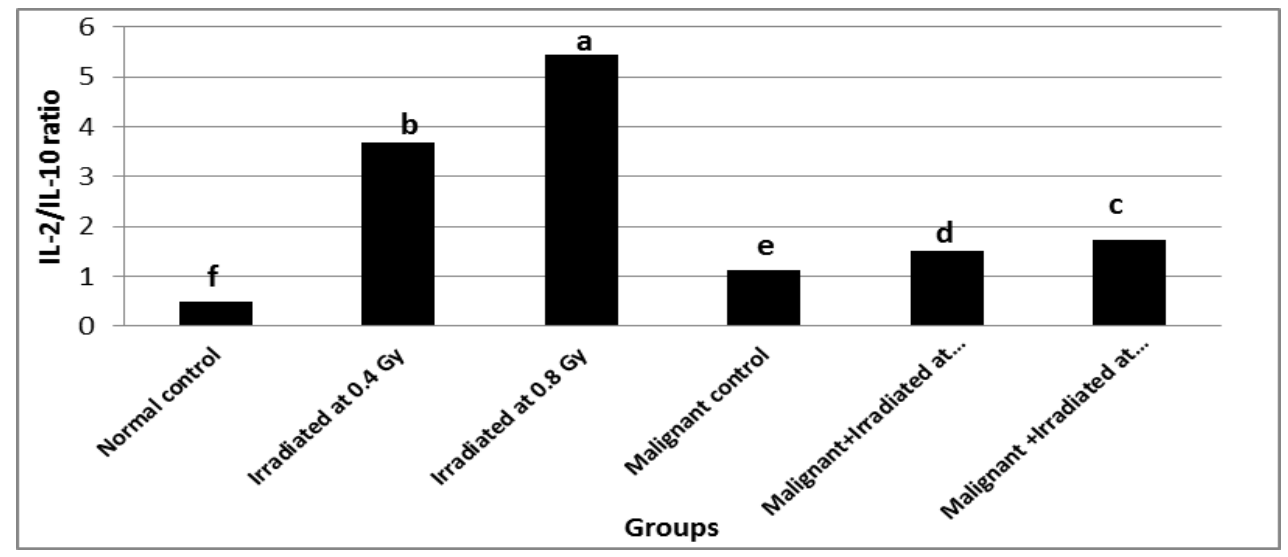

Figure 2. Illustrates IL2/ IL10 (Th1/Th2 balance) in all the tested groups. Bars not sharing the same letters are significantly different from each other $(p<0.05)$.

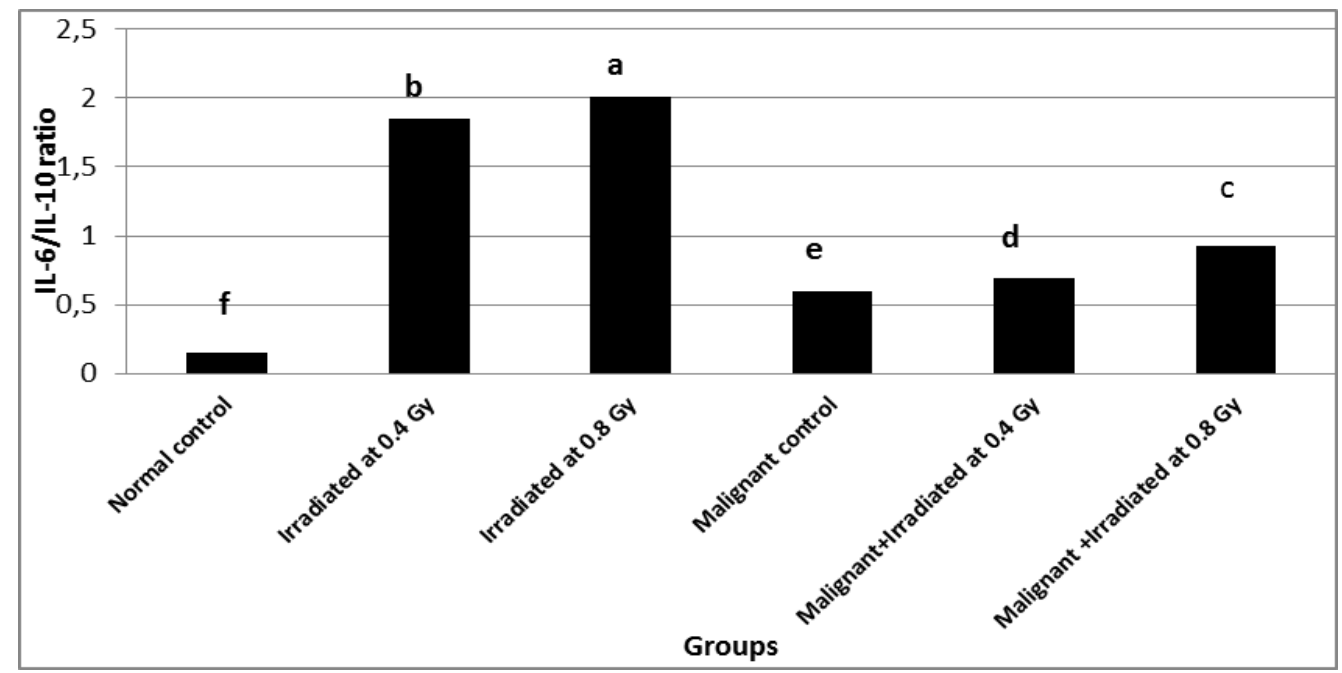

Figure 3. Illustrates IL6/ L10 ratio (pro/anti-inflammatory cytokine ratio) in all the tested groups.Bars not sharing the same letters are significantly different from each other $(p<0.05)$.

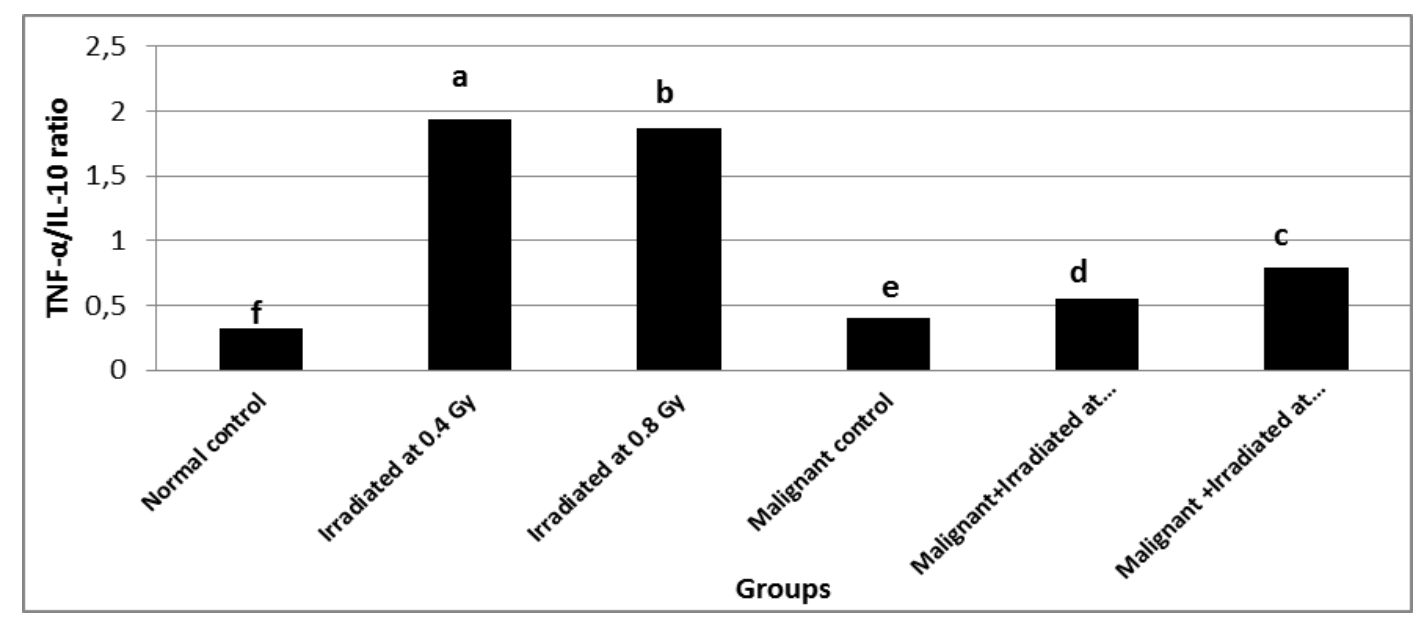

Figure 4. Illustrates TNF- $\alpha$ / IL10 ((pro/anti-inflammatory cytokine ratio) in all the tested groups, Bars not sharing the same letters are significantly different from each other $(p<0.05)$. 
Figure 5 revealed that low-dose $\gamma$ irradiation (0.4 Gy or 0.8 Gy) significantly depressed tumor growth in mice implanted with Ehrlich Ascites Carcinoma. The average tumor sizes of the irradiated mice at the two doses were significantly smaller than that of the non irradiated malignant mice throughout 3 weeks.
Figure 6 illustrates that the percentage reduction of the solid Ehlich Carcinoma tumor size of the two irradiated carcinoma groups were $19.67 \%$ (G5) and $-21.48 \%$ (G6) in relation to the only malignant groups(G4) at the end of 21 days, taking in consideration that the tumor size of $0.8 \mathrm{~Gy}$ (G6) was more reduced than $0.4 \mathrm{~Gy}(\mathrm{G} 5)$ by $1.81 \%$.

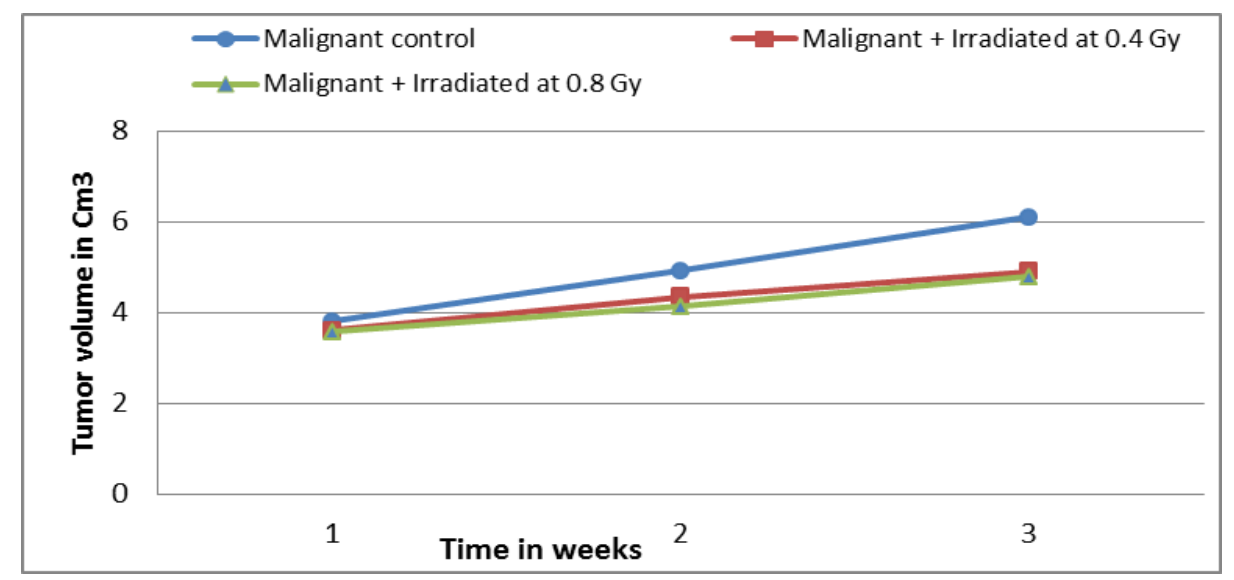

Figure 5. The average change in Ehrlich tumor size in two irradiated malignant groups per week throughout a 3 weeks.

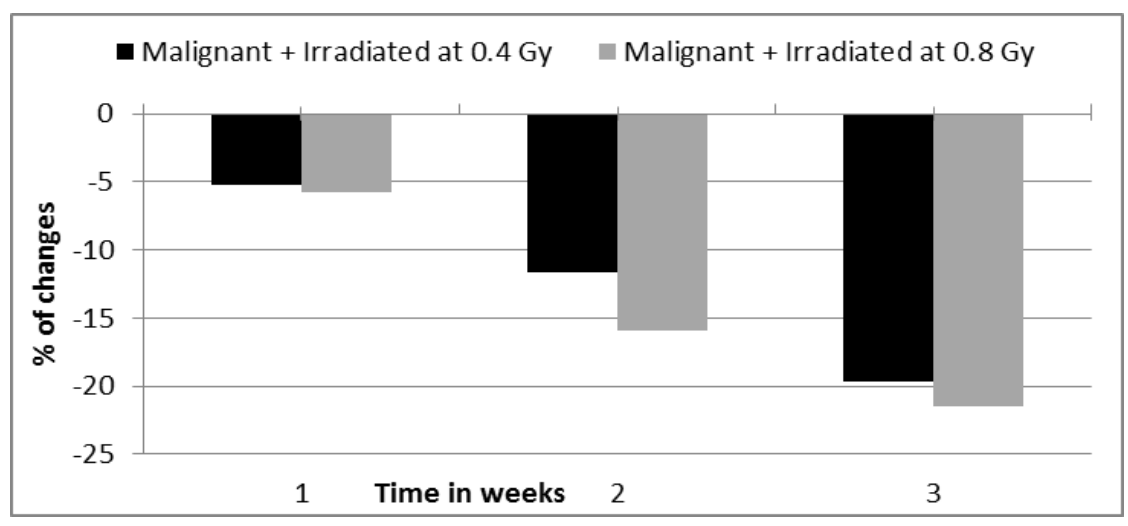

Figure 6. Illustrates the percent of changes of the Ehrlich tumor sizes in the two irradiated malignant groups relative to the malignant control throughout three weeks.

Table 2 and Figure 7 demonstrate means \pm $\mathrm{SD}$ and percent of the changes from normal control of the total proteins, albumin and globulin for all the tested groups. The data showed that total protein and albumin were significantly decreased $p<0.05$ in
G3(Irradiated at 0.8 Gy) and G6 (Malignant + Irradiated at $0.8 \mathrm{~Gy}$ ) relative to normal control group. Also, there were significant decreases in total proteins and albumin in G6, relative to malignant control group.

Table 2. Effect of radiation exposure at 2.4 and 4.6 (accumulation of 0.4 and 0.8 respectively) on total proteins, albumin and globulin on in different animal groups.

\begin{tabular}{llll}
\hline \multicolumn{1}{c}{$\begin{array}{c}\text { Parameters } \\
\text { Groups }\end{array}$} & TP g/dl & Alb. g/dl & Glob. g/dl \\
\hline Normal control (G1) & $4.74 \pm 0.46^{\mathrm{a}}$ & $2 . .61 \pm 0.50^{\mathrm{a}}$ & $2.13 \pm 0.08^{\mathrm{a}}$ \\
Irradiated at & $4.58 \pm 0.38^{\mathrm{a}}$ & $2.56 \pm 0.18^{\mathrm{a}}$ & $2.02 \pm 0.19^{\mathrm{a}}$ \\
0.4 Gy (G2) & $3.89 \pm 0.25^{\mathrm{b}}$ & $1.91 \pm 0.15^{\mathrm{b}}$ & $1.98 \pm 0.09^{\mathrm{a}}$ \\
Irradiated by & & & \\
0.8 Gy (G3) & & & \\
\hline
\end{tabular}




\begin{tabular}{llll}
\hline Malignant control (G4) & $4.66 \pm 0.46^{\mathrm{a}}$ & $2.68 \pm 0.20^{\mathrm{a}}$ & $1.98 \pm 0.29^{\mathrm{a}}$ \\
Malignant + Irradiated at & $4.34 \pm 0.45^{\mathrm{a}}$ & $2.37 \pm 0.17^{\mathrm{a}}$ & $1.97 \pm 0.28^{\mathrm{a}}$ \\
0.4 Gy (G5) & & & \\
Malignant + Irradiated at & $3.27 \pm 0.17^{\mathrm{c}}$ & $1.44 \pm 0.19^{\mathrm{c}}$ & $1.84 \pm 0.33^{\mathrm{a}}$ \\
0.8 Gy (G6) & & & \\
\hline
\end{tabular}

Data represented as mean \pm SD ; Means with different superscripts in the same Colum are significantly different $(\mathrm{P}<0.05)$.

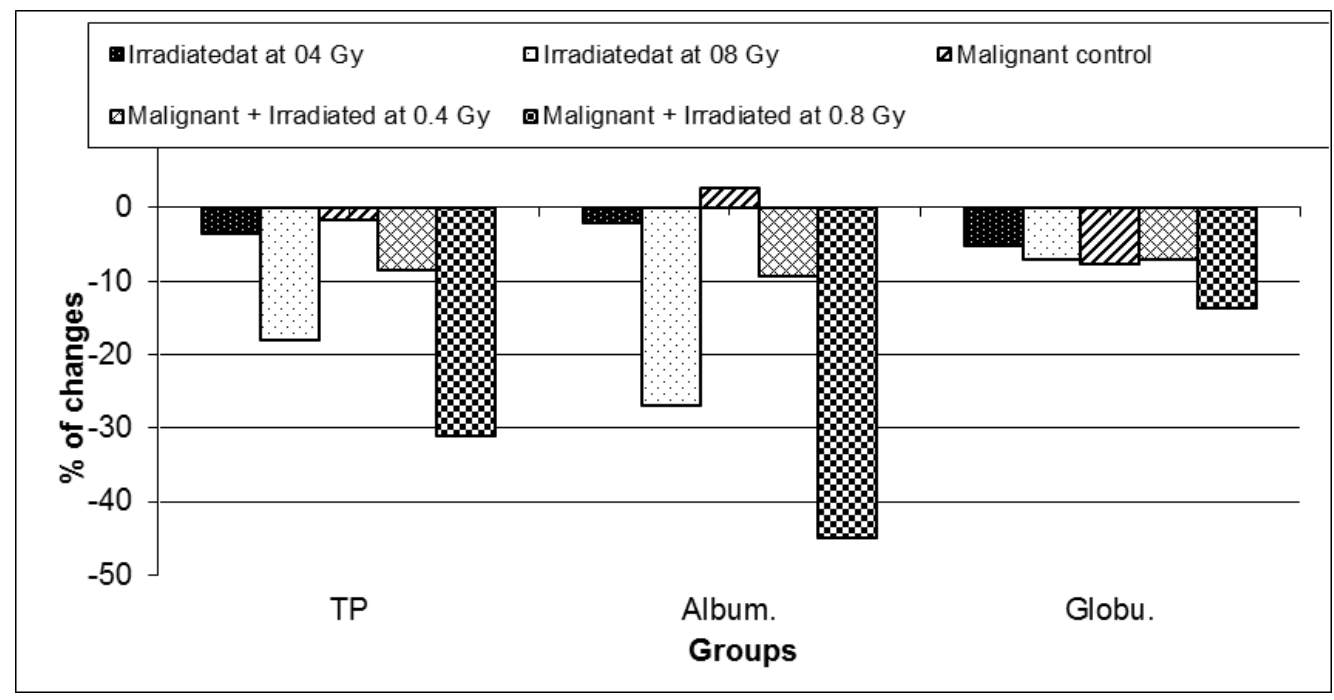

Figure7. Illustrates the percent of changes of total proteins, albumin and globulin in all the tested groups in relation to normal control.

\section{DISCUSSION}

It is clear that the radiotherapy is extensively used against tumor growth. However, high doses of radiation often cause harmful effects to normal cells whereas low doses of irradiation show several benefits to living organisms through immune response enrichment (LIU, 2007). Cytokines are the most important mediators by which cells of immune system have been communicated (BOGDANDI et al., 2010). In this current work we aimed to study certain cytokines and their relationship with each other to reflect the functional integrity of the immune system and hence the improvement of the efficacy of the therapy in cancer treatment.

In the current study, radiation treatment by different two doses $(0.4$ or $0.8 \mathrm{~Gy})$ led to the changing of several cytokines production. In group 2 (normal mice+ Irradiated at $0.4 \mathrm{~Gy}$ ) and group 3(normal mice+ Irradiated at $0.8 \mathrm{~Gy}$ ) there were significant up-regulated in IL2, IL6 and TNF- $\alpha$ and down-regulated in IL-10 level, and 0.8 Gy dose is more effective than 0.4 Gy dose compared to normal control. This may be due to LDR increased capacity of $T$ cells to produce immune enhancing cytokines (IL-2), while decreasing production of a major anti-inflammatory cytokines (IL10), so enhancement of immune response. our results recorded significant increases in IL2/IL10 ratio (Th1/Th2 balance), IL6/IL10 and TNF- $\alpha /$ IL10 ratio in two normal irradiated groups with high significant increase in 0.8 Gy dose than 0.4 Gy dose $\gamma$ - radiations compared to normal control group (Figure 4,5\&6). Therefore, shifts in the immunity balance towardTh1 polarization. This result is in agreement with Shigematsu et al. (2007) who observed that the $0.05 \mathrm{~Gy}$ pre-irradiated dendritic cells showed the highest proliferation capacity of $\mathrm{T}$ cells, and confirmed the production of IL-2, IL-12. Moreover, Farahat et al.( 2017) reported that there is statistically significantly higher level of Th1 cytokines (IL2, IFN $\gamma$ ) along with statistically significant lower levels of Th2 cytokines ( IL10) associated with lower CD4\% among the physicians exposed to low dose ionizing radiation compared to control groups $(\mathrm{P}<0.05)$. Zakeri et al. $(2010)$ observed that a significant serum increase of IL-2 and decrease of IL-10 in the low-dose X-ray radiation exposure on Interventional cardiologists group compared with the control.

The obtained results showed significant elevation in the level of IL2, IL6 and TNF- $\alpha$ and decrease in IL10 in group 4 in tumor bearing mice compared to normal control group this may be due to tumor lymphocytes secrete pro-inflammatory 
cytokines (IL-6 and TNF- $\alpha$ ) which increase expression of vascular endothelial growth factor (VEGF), is the key mediator of angiogenesis in tumor cells, promoting angiogenesis (HAMED et al., 2012; ANGELO et al., 2007). These finding may be attributed to the exposure to low doses enhance the immunological responses especially (1L-2 and TNF- $\alpha$ ) and this is the aim of the presented study. Moreover the increase of IL- 6 levels with different significant values due to its role in the immunological response (inflammation and healing). The significant decrease in IL-10, immunosuppressive, in (G4) may be due to immune surveillance of host against tumor which indicated by significant increases in IL2/IL10 ratio (Th1/Th2 balance), IL6/IL10 and TNF- $\alpha /$ IL10 ratio, which indicate enhancement of immune response. Mocellin et al. (2005) reported that IL-10 is an immunosuppressive molecule secreted by tumors to allow malignant cells to escape from immune surveillance. So, the decrease in IL-10 in this study indicates the increases immune surveillance of host against tumor.

The present study recorded that the significant increase in IL2, IL6 and TNF- $\alpha$ and significant decrease in IL10 in EAC tumor mice exposed to 0.4 or 0.8 Gy radiation, and this positive effect is more in EAC tumor mice exposed to 0.8 Gydose than 0.4 Gy dose of radiation in comparing with malignant control that might be reflect the ability of LDR to stimulate immunity by concerns most anticancer parameters, including antibody formation, natural killer (NK) and macrophage activity, secretion of cytokines as well as other cellular changes. Also, there were significant increases in IL2/IL10 ratio (Th1/Th2 balance), IL6/IL10 and TNF- $\alpha /$ IL10 ratio in two groups of EAC tumor mice exposed to $0.4(\mathrm{G} 5)$ or 0.8 Gy (G6) radiation with high significant increase in 0.8 Gy dose than 0.4 Gy dose $\gamma$ - radiations compared to malignant control group (Figure 4, 5, 6). This result indicates LDR induces a shift in cytokine profile from Th2 (IL-10) to Th1 in EAC tumor mice, suggesting an enhancement of Th1mediated anti-tumor immune response and $0.8 \mathrm{~Gy}$ LDR has more positive effective on anti-tumor immune response than 0.4 Gy LDR. Liu (2007) showed that LDR significantly up regulate IL2 and TNF- $\alpha$ and down-regulated the elevated IL-10, these indicate a positive effects of LDR on immune enhancement. Furthermore, Farooque et al.(2011) reported that LDR stimulates the immune system by activating innate immune cells in addition to enhancing $\mathrm{T}$ - and B-cell responses by critically balancing the cytokine profile (shift from $\mathrm{Th} 2$ to
Th1), leading to effective anti-tumor immunity. Also, Sun; Liu, (2000) and Hayase et al. (2008) showed that exposure to low-dose irradiation not only reduces the secretion of immunosuppressive cytokines such as IL-10 and TGFb, but also supports proliferation of cells by the secretion of growth-stimulatory Th1 cytokines such as IFN-g, IL-2 and TNF- $\alpha$.

Concerning the effect of the two low doses (0.4 accumulated up to 2.4 Gy and $0.8 \mathrm{~Gy}$ accumulated up to $4.8 \mathrm{~Gy}$, at the end of 3 weeks) $\gamma$ irradiation on tumor sizes in the present study, revealed that prominent inhibition of tumor sizes in both groups of malignant and irradiated mice less than the malignant control mice (Fig 5). The tumor size of the two groups of irradiated and malignant mice (at accumulated doses 2.4 and 4.8Gy) were slightly differing. It has already reported that low dose ionizing radiation exerts carcinostatic effects. Hosoi; Sakamoto, (1993) recorded a suppression of artificial and spontaneous lung metastases in mice following low dose (0.15-0.2 Gy) irradiation. Nowosielska et al.(2008) reported the pronounce inhibition of tumor growth following LDR is attributed to stimulation of anti-tumor defense reactions mediated by NK cells and /or macrophages. Golden et al.(2012); Watten berg et al.(2014) confirmed that the ionizing radiation overcome cancer cells through different mechanisms of cancer cell death including apoptosis, necrosis, mitotic catastrophe and immunogenic cell death. Repeated low doses of 0.5 Gy/ 4days up to 2 Gy accumulated dose, $\gamma$ irradiation significantly delayed tumor growth in mice implanted with EAC(KOJIMA, 2006). Moreover, Zhang et al.(1998) showed that low dose $\mathrm{X}$-rays reduces metastasis of implanted B16 melanoma and Lewis lung cancer in $\mathrm{C} 57 \mathrm{BL} / 6 \mathrm{~J}$ mice. In addition, Jin et al (1997) reported reduction in growth rate of tumors as well as metastasis in different strains of mice exposed to low-dose x-rays and $\gamma$-rays.

Proteins are important building blocks of cells, tissues and vital for body growth, development and health (RASOULI et al., 2005). In the present study, total proteins and albumin were significantly decreased in mice of G3 (irradiated at 0.8 Gy) and in mice of G6 (malignant -irradiated at $0.8 \mathrm{~Gy}$ ) this decrease in total protein in both two groups might be referred to the effect of radiation which may be leads to damage of vital biological processes or to changes in permeability of liver, kidney and other tissue cells leading to leakage of proteins via the kidney (CHOLDHARI; CHAKRABARTI, 1983). This obtained result 
agreement with Viana et al (2016) who showed that a significant decrease in total protein and albumin in rats exposed to low-dose total body irradiation. Also, Vilić et al. (2014) observed that the total protein, albumin and globulin fraction concentration were significantly decreased in the blood plasma of chickens hatched from irradiated eggs with a dose of 0.15 Gy gamma-rays (60Co) before incubation. The low dose of gamma radiation may be having limited side effects on liver and kidney functions.

\section{CONCLUSION}

The present work reinforces the beneficial effect of fractionated total body low dose gamma irradiation $(0.4 \mathrm{~Gy}$ or $0.8 \mathrm{~Gy})$ in the regression of implanted Ehrlich Ascites Carcinomain BALB/c mice.

\section{ACKNOWLEDGEMENT}

This study was supported by Biological Applications Department, Nuclear Research Centre, Atomic Energy Authority, Egypt.

\begin{abstract}
The positive impact of exposure to low-dose gamma irradiation (LDR) on tumor regression and immune response has recently been emphasized. The present study aimed to investigate the Thelper 1/ T-helper 2 (Th1/ Th2) cytokine balance, serum protein changes in male BALB/c Ehrlich Ascites Carcinoma (EAC) bearing mice exposed to two low doses $(0.4 \mathrm{~Gy}$ or $0.8 \mathrm{~Gy})$ of gamma irradiation. Seventy two male BALB/C mice were divided into six groups. Group1: normal control; Group2\&3:mice were exposed to $\gamma$ irradiation at 0.4 and 0.8 Gray, respectively two times weekly for 3 weeks; Group4 (malignant control):mice were injected subcutaneously with $2 \times 10^{6}$ Ehrlich Ascites Carcinoma (EAC) cells/mouse; Group5\&6: mice were injected by EAC cells and exposed to $\gamma$-irradiation at 0.4 and 0.8 Gray, respectively two times weekly for 3 weeks, eight days after tumor transplantation. Data from the present study reported that two low-doses of $\gamma$ irradiation significantly increase the levels of serum IL2, IL6 and TNF $\alpha$ and a decrease the serum IL10 level in comparison to malignant control mice. The IL2 /IL-10,IL-6/IL-10 and TNF $\alpha /$ IL-10 (Th1/Th2 balance), were significantly increased in all tested groups when compared with control $(\mathrm{P}<0.05)$. Exposure to 0.8 Gy dose, however, induced significant elevation in all ratios in comparison to exposure to 0.4 Gy dose. This was associated with significant reduced tumor growth in mice implanted with Ehrlich Ascites Carcinoma, which was more pronounced in mice exposed to 0.8 Gy than mice exposed to 0.4 Gy dose. In conclusion, the present study suggests a possible immunomodulatory role of LDR as it was associated with Th1 cytokine polarization response, and 0.8 Gy have more positive effect than $0.4 \mathrm{~Gy}$. It also reinforces the beneficial effect of accumulated dose of total body irradiation $(0.4 \mathrm{~Gy}$ or $0.8 \mathrm{~Gy}$ ) in the regression of implanted Ehrlich Ascites Carcinomain BALB/c mice.
\end{abstract}

KEYWORDS: Ehrlich Ascites Carcinoma. $\gamma$-radiation. Cytokines.

\title{
REFERENCES
}

AKDIS, M.; BURGLER, S.; CRAMERI, R., EIWEGGER, T.; FUJITA, H.; GOMEZ, E.; KLUNKER,S.; MEYER, N.; O'MAHONY, L.; PALMARES, O.; RHYNER, C.; OUAKED, N.; SCHAFFARTZIK, A.; VAN, D. V.; ZELLER, S.; ZIMMERMANN, M., AKDIS, C. A. Interleukins, from 1 to 37, and interferon-gamma: receptors, functions, and roles in diseases. J Allergy Clin. Immunol, v. 127, p. 701-21, 2011. https://doi.org/10.1016/j.jaci.2010.11.050

ANGELO, L. S.; KURZROCK, R. Vascular endothelial growth factor and its relationship to inflammatory mediators. Clin Cancer Res, v. 13, N. 10, P.2825-2830, 2007. https://doi.org/10.1158/1078-0432.CCR-062416

BOGDANDI, E. N.; BALOGH, A.; FELGYINSZKI, N.; et al. Effects of low-dose radiation on the immune system of mice ater total-body irradiation. Radiation Research, v. 174, n. 4, p.480-489, 2010. https://doi.org/10.1667/RR2160.1 
CHEN, Y.; HYRIEN, O.; Williams J, Okunieff P, Smudzin T, Rubin P. Interleukin (IL)-1A and IL-6: Applications to the predictive diagnostic testing of radiation pneumonitis. Int J Radiat Oncol Biol Phys., v. 62, p. 260-266, 2005. https://doi.org/10.1016/j.jijrobp.2005.01.041

CHOLDHARI, P. D.; CHAKRABARTI, C. H. Effect of Isofenphos (oftanol) \& Acephate (orthene) on fecal bile acids, cholesterol \& total protein content of serum \& liver in albino rats. Ind J Exp. Biol ., v. 21, p. 684, 1983.

DUNN, G. P.; OLD, L. J.; SCHREIBER, R. D. The three Es of cancer immunoediting.Annu. Rev. Immunol. V. 22, p. 329-360, 2004. https://doi.org/10.1146/annurev.immunol.22.012703.104803

FARAHAT, S. A.; MANSOUR, N.; SHETA, M.; RAMADAN, M. A. Immune-modulatory Effect of Ionizing Radiation on Type 1 and Type 2 Immune Responses among Workers in Cardiac Catheterization Units . British Journal of Medicine \& Medical Research, v. 19, n. 2, p. 1-10, 2017. https://doi.org/10.9734/BJMMR/2017/29663

FAROOQUE, A.; MATHUR, R.; VERMA, A.; et al. Low-dose radiation therapy of cancer: role of immune enhancement. Expert Rev Anticancer Ther., v. 11, p. 791-802, 2011.

GOLDEN, E. B.; PELLICCIOTTA, I.; DEMARIA, S.; BARCELLOS-HOFF, M. H.; FORMENTI S. C. The convergence of radiation and immunogenic cell death signaling pathways. Front. Oncol., v. 2, p. 88, 2012. https://doi.org/10.3389/fonc.2012.00088

GOTHOSKAR, S. V.; RANADIVE, K. J. Anticancer screening of SAN-AB: an extract of marking nut Semicarpusanacardium. Indian J Exp Biol., v. 9, p. 372-375, 1971.

HAMED, E. A.; ZAKHARY, M. M.; MAXIMOUS, D. W. 2012. Apoptosis, angiogenesis, inflammation, and oxidative stress: basic interactions in patients with early and metastatic breast cancer. J Cancer Res Clin Oncol., v. 138, n. 6, p. 999-1009, 2012. https://doi.org/10.1007/s00432-012-1176-4

HAYASE, H.; OHSHIMA, Y.; TAKAHASHI, M.; ET AL. The enhancement of Th1 immunity and the suppression of tumor growth by low-dose g -radiation. Int J Low Radiat., v. 5, n. 4, p. 275-289, 2008. https://doi.org/10.1504/IJLR.2008.020977

HOSOI, Y.; SAKAMOTO, K. Suppressive effect of low dose total body irradiation on lung metastasis: dose dependency and effective period. Radiother Oncol., v. 26, p. 177-179, 1993. https://doi.org/10.1016/01678140(93)90101-D

JIN, A. X.; WANG, S. Y.; WEI, D. Y. Mechanism of Low Level Ionizing Radiation in Inhibiting B16 Melanoma Blood-born Pulmonary Metastasis. Chin J Radiol Med Prot. , v. 17, p. 236-239, 1997.

KIDD, P. Th1/Th2 balance: the hypothesis, its limitations, and implications for health and disease.

Altern.Med. Rev., v. 8, n. 3, p. 223-246, 2003.

KOJIMA, S. Induction of glutathione and activation of immunefunctions by low-dose, whole body irradiation with $\gamma$-rays[in Japanese]. YakugakuZasshi, v. 126, n. 10, p. 849-857, 2006.

https://doi.org/10.1248/yakushi.126.849

LIU, S. Z. Cancer control related to stimulation of immunity by low-dose radiation. Dose Response, v. 5, n. 1, p. 39-47, 2007. https://doi.org/10.2203/dose-response.06-108.Liu

MARY, M.; TOMAYKO, P.; REYNOLDS, C. P. Determination of subcutaneous tumor size in athymic (nude) mice, Cancer ChemotherPharmacol v. 24, p. 148-154, 1989. https://doi.org/10.1007/BF00300234 
MOSMANN, T. R.; CHERWINSKI, H.; BOND, M. W. GIEDLIN, M. A.; COFFMAN, R. L. Two types of murine helper T cell clone. I. Definition according to profiles of lymphokine activities and secreted proteins. J. Immunol, v. 136, p. 2348-2357, 1986.

MOCELLIN, S.; MARINCOLA, F. M.; YOUNG, H. A. Interleukin-10 and the immune response against cancer: a counterpoint. Journal of Leukocyte Biology, v. 78, n. 5, p. 1043-1051, 2005.

https://doi.org/10.1189/jlb.0705358

NOWOSIELSKA, E.M.; CHEDA, A.; WREMBEL-WARGOCKA, J.; JANIAK, M. K. Modulation of the growth of pulmonary tumour colonies in mice after single or fractionated low-level irradiations with X-rays. NUKLEONIK, v. 53, n. 1, p. S9-S15, 2008.

RASOULI, M.; OKHOVATIAN, A.; ENDERAMI, A. Serum proteins profile as an indicator of malignancy: multivariate logistic regression and ROC analyses. Clin Chem Lab Med., v. 43, n. 9, p. 913-8, 2005. https://doi.org/10.1515/CCLM.2005.156

RATTAN, S. I. Hormesis in aging. Ageing Res. Rev, v. 7, n. 1, p. 63-78, 2008. https://doi.org/10.1016/j.arr.2007.03.002

SHIGEMATSU, A., ADACHI, Y., KOIKE-KIRIYAMA, N., et al. 2007. Effects of low-dose irradiation on enhancement of immunity by dendritic cells. J. Radiat. Res. 48:51-55. https://doi.org/10.1269/jrr.06048

SUN, Y. M.; LIU, S. Z. Changes in TNFa expression in mouse peritoneal macrophages after whole body xray irradiation. J. Radiat. Res., v. 18, p. 235-239, 2000.

VIANA,W. C. M.; LAMBERTZ, D.; BORGES, E. S.; NETO, A. M. O.; KMFT, L.; AMARAL, A. who showed that a significant decrease in total protein and albumin in rats exposed to low-dose total body irradiation. Appl Radiat Isot, v.118, p.232-237, 2016.

VILIĆ, M.; KRALJEVIĆ, P.; ŽURA, Ž. I.; HLEDEP, J.; MILJANIĆ, S.; ŠIMPRAGA, M. Concentration of proteins and protein fractions in blood plasma of chickens hatched from eggs irradiated with low dose gamma radiation. Veterinarsk Arhiv, v. 84, n. 4, p. 401-409, 2014.

WANG, F.;ARUN, P.; FRIEDMAN, J.; CHEN, Z.; VAN, W. C. Current and potential inflammation targeted therapies in head and neck cancer. Curr. Opin Pharmacol, v. 9, p. 389-95, 2009.

WATTENBERG, M. M.; KWILAS, A. R.; GAMEIRO, S. R.; DICKER, A. P.; HODGE, J. W. Expanding the use of monoclonal antibody therapy of cancer by using ionising radiation to upregulate antibody targets.

British Journal of Cancer, v. 110, p. 1472-1480, 2014. https://doi.org/10.1038/bjc.2014.79

ZAKERI, F.;HIROBE, T.; AKBARINOGHABI, K. Biological effects of low-dose ionizing radiation exposure on interventional cardiologists. Occupational Medicine, v. 60, p. 464-469, 2010. https://doi.org/10.1093/occmed/kqq062

ZHANG, Y.; LU, Z.; LI, X. Y. Influence of Low Dose Radiation on the Pulmonary Metastasis of Lewis Lung Carcinoma in Mice. J N Bethune Univ Med Sci, v. 24, p. 559-562, 1998. 